\title{
Investigation to track the environmental impact of the COVID-19 pandemic in Pakistan
}

\author{
Abdul Rehman \\ College of Economics and Management, Henan Agricultural University Zhengzhou 450002, \\ China \\ Email Id: abdrehman@henau.edu.cn
}

\begin{abstract}
Coronavirus disease is a newly identified infectious disease that began in Wuhan, China in 2019 and is recognized as COVID-19. This virus has a serious impact on the planet that causes the deaths of millions of people; it produces unemployment and poverty. However, it has constructive environmental effects that reduce the amount of pollution in the atmosphere. Pakistan is also a developing economy caused by this deadly virus. Before 03 April 2021, the percentage of reported cases ranges from 682,888 , with about 14,697 casualties and a total of 609,691 cases retrieved. Pakistan's war against coronavirus can differ from advanced technical countries due to lack of resources. In this article, we will address the relation between COVID-19 and the environment in the particular case of Pakistan. There is evidence that this pandemic has lowered concentrations of greenhouse gases, including $\mathrm{CO} 2$ and $\mathrm{NO} 2$, as a consequence of global lock-down strategies.
\end{abstract}

Keywords: COVID-19; environment; CO2 emission; temperature; NO2 emission; energy

\section{Introduction}

The human beings have been met by lethal and infectious diseases that killed the tens of millions of people. In Wuhan, Hubei Province of China, the COVID-19 Pandemic was identified first and rapidly spread worldwide in. The worst-affected nations in the world are the United States, China, Spain, Germany, Italy and France. Over a span of four months after the first epidemic in Wuhan, China, the lethal virus has affected more than 1 million people, forcing them to implement lock-down protocols to mitigate the notorious virus (Manigandan et al. 2020a; Nižetić 2020; Le et al 2020). This pandemic (COVID-19) has severely impacted the world economy and putted many countries into crises. Necessary precautions should be 
taken to maintain a safe life and good hand hygiene, such as regular hand washing with water and soap, avoid and strengthen the immune system to prevent the spread of this disease (Vochozka et al. 2019; Mahmood et al. 2020).

A considerable concern in the global health system is the high incidence of COVID-19 infections in Europe since diagnoses of COVID-19 cases are dependent on the epidemiological monitoring capabilities of European countries. Early tests found that incubating COVID-19 to humans requires up to two weeks. However, significant measures are important in the present situation to avoid the further spread of the emerging coronavirus. The most practical method to monitor COVID-19 delivery is to constantly prepare and upgrade health services at the time which are only assessments accessible (Bashir et al. 2020; Dutheil et al. 2020; Cheung et al. 2020). According to several reports, COVID 19 has an improved impact on public wellbeing in the case of air contamination. The COVID-19 Pandemic in developing countries that reside in areas with poor urban air quality is also affected by a significant proportion of the population (Wu et al. 2019; Wang et al. 2020; Wu et al. 2020; Zhang et al. 2020).

The air pollution causes the temperature and which may trigger radical environmental changes, and can also intensify outbreaks of infectious diseases by influencing reservoirs and complex dissemination (Hayes et al. 2018; Howard and Huston 2019; Jia et al. 2020). As we are all conscious, the virus has no immediate influence except on the atmosphere and the energy industries. However, social conditions which can impact the atmosphere and the energy sector indirectly. There are clear and active country actions to deter this pandemic (Eroğlu 2020). Furthermore, major rainfall shifts were recorded due to the decrease in greenhouse gases. In addition, the accumulation of toxins declines as indoor instructions remain (Saravanan 2020). The global COVID-19 disturbance has had a variety of environmental and climatic consequences. Because of travel limits and severe economic and 
social slowdowns, air quality increased in many cities and water contamination has declined across the world.

\section{Pollution Scenario in Pakistan and Globally}

When the population is rising exponentially, it causes the growing concern to air pollution. The rise in air quality is attributed primarily to industrialization, urbanisation and forest degradation. Wind contamination is seen as a significant danger to the climate. The household and the automotive industry are different causes of air pollution (Maroušek et al. 2020). The situation is positive, though contamination has been minimised and greenhouse gas emissions have greatly increased air and water excellence. Though air pollution is decreased, bodies of water are cleaned and the sky has turned blue in some of the most industrialised areas. The citizens have been enjoying the cleanest air following the declaration of the first national lockdown. The climate has improved positively around the globe, some of which were experienced decades back (Lokhandwala and Gautam 2020; Bahukhandi et al. 2020).

The contamination caused by increased particulate matter, especially for a short period, impacts the community considerably and eventually affects human health. Keeping environmental quality allowable and maintaining a strategic gap against dangerous effects on local air emissions inhabitants. Each year human pollutants create unsafe air quality (WHO 2020). Emission of $\mathrm{CO} 2$ contributes to significant adjustments in temperature. The global temperature increase, which cannot be ignored, has hit a high degree. Greenhouse gas emissions (GHGs) indicate an improvement in global warming and temperature (Requia et al. 2018; Rupani et al. 2020).

The NO2 emission situation for mega-cities in Pakistan, such as Hyderabad, Islamabad, Karachi, Lahore, Peshawar and Quetta, is seen in Figure 1. The figure reveals that the major 
contributors for NO2 pollution in Pakistan are Lahore and Islamabad in comparison with other cities. The detail is taken from pictures of the NSA-2021 (NASA 2021). Figure 2 also demonstrates the patterns in Pakistan's NO2 emissions.

Researchers and policy makers are still worried about the continuing decline of fossil resources and their adverse impacts on our climate. There have lately been tremendous improvements in the way energy is produced from clean energy sources including sun, wind, mains and other green energy technologies. The shift from an economy of fossil fuels to sustainable bio-economics can, in particular, be promoted through bio-based alternative fuel such as biomass, biodiesel and biogas (Hussain et al. 2017; Khare et al. 2016; Manigandan et al. 2020). It is, though, still paid for certain things, such as the abrupt halt in waste and toxins added in river water specifically or indirectly, less barriers in the path of wild beasts and less causational ties to humans attributable to road collisions (Pani et al. 2020; Chen and Chen 2021).

The temperature variations scenario in the world is presented in the Figure 3 from 1980-2019. Figures shows that how temperature was increased with passage of time. The temperature of the world is increasing with the passage of time and getting warmer. It is associated with the industrial revolution, which increased reading. Other reason is a mixture of human activities and certain natural differences. 

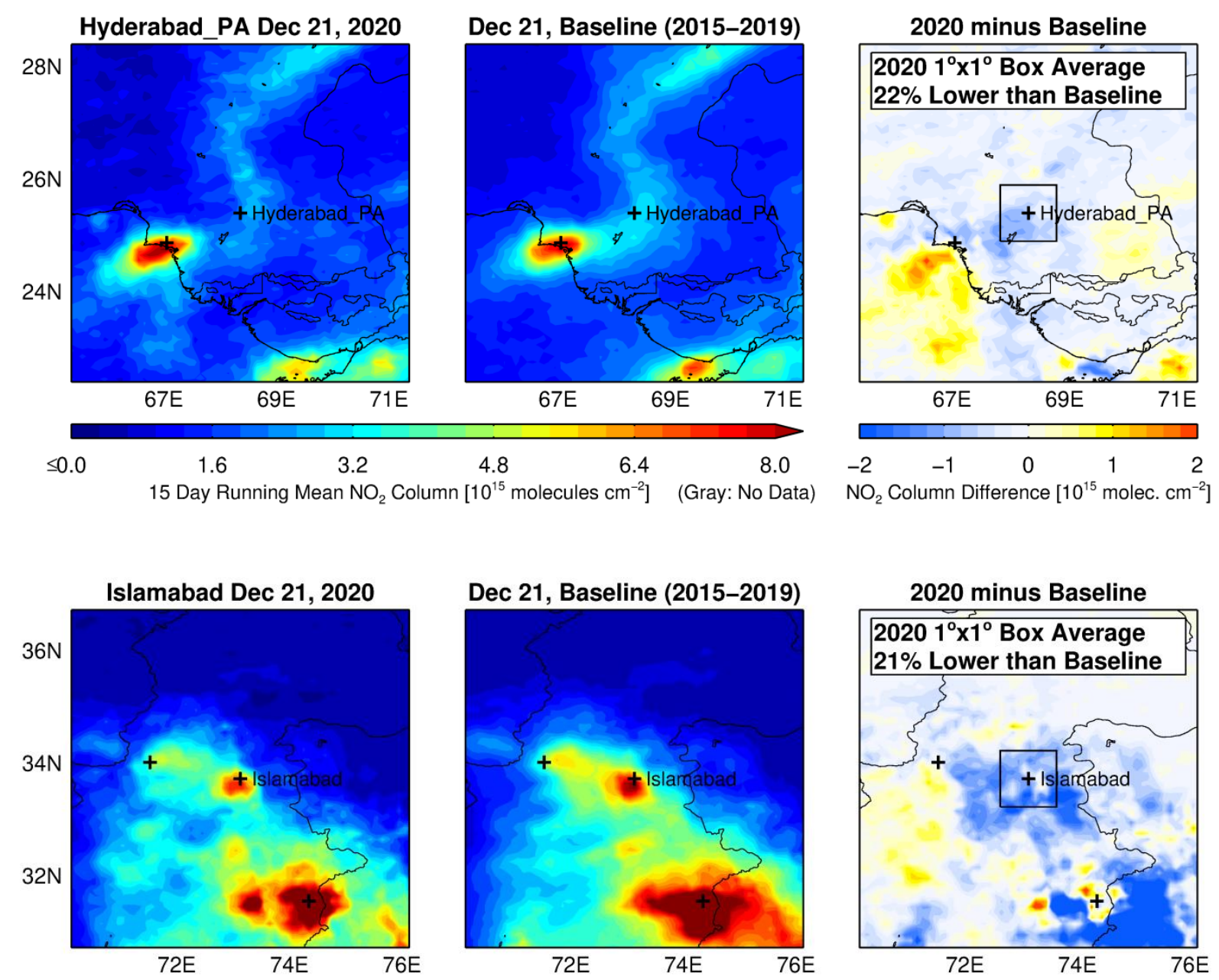

$\leq 0.0$

$$
1.6
$$

3.2

4.8

6.4

8.0

15 Day Running Mean $\mathrm{NO}_{2}$ Column $\left[10^{15}\right.$ molecules $\left.\mathrm{cm}^{-2}\right]$ (Gray: No Data)

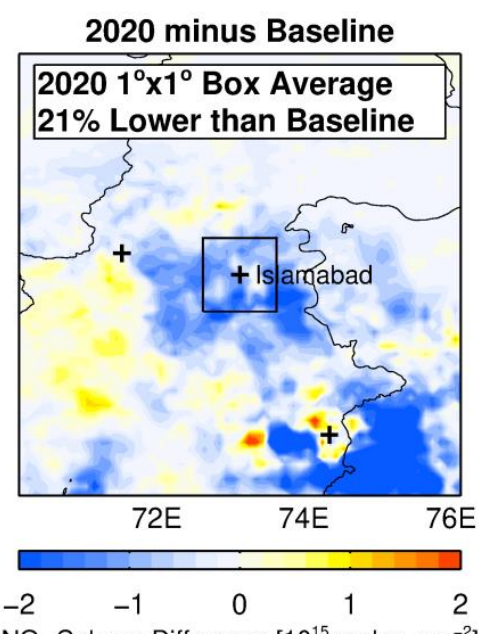

$\mathrm{NO}_{2}$ Column Difference $\left[10^{15}\right.$ molec. $\left.\mathrm{cm}^{-2}\right]$ 

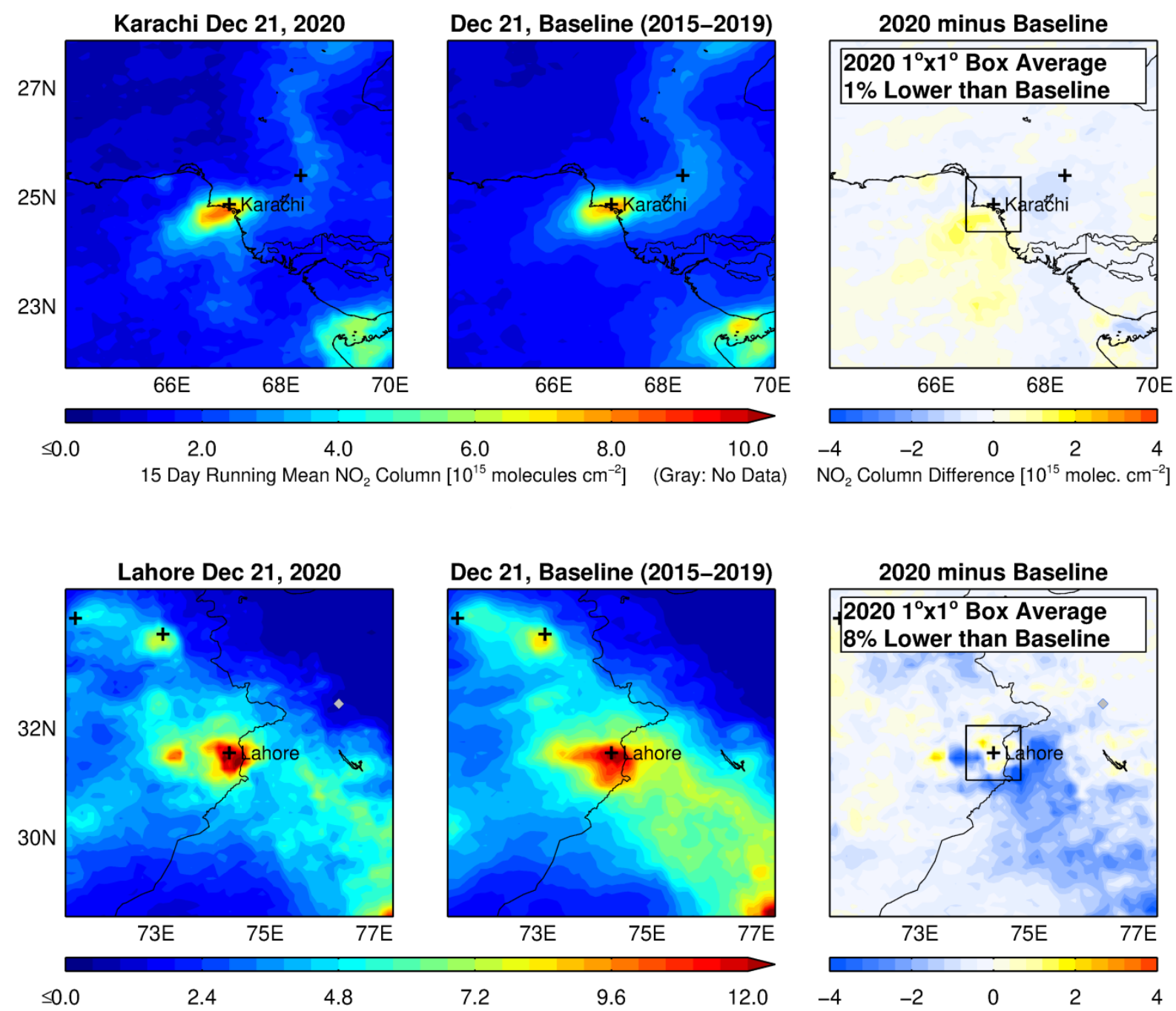

15 Day Running Mean $\mathrm{NO}_{2}$ Column $\left[10^{15}\right.$ molecules $\left.\mathrm{cm}^{-2}\right]$ (Gray: No Data)

$\mathrm{NO}_{2}$ Column Difference $\left[10^{15}\right.$ molec. $\left.\mathrm{cm}^{-2}\right]$ 

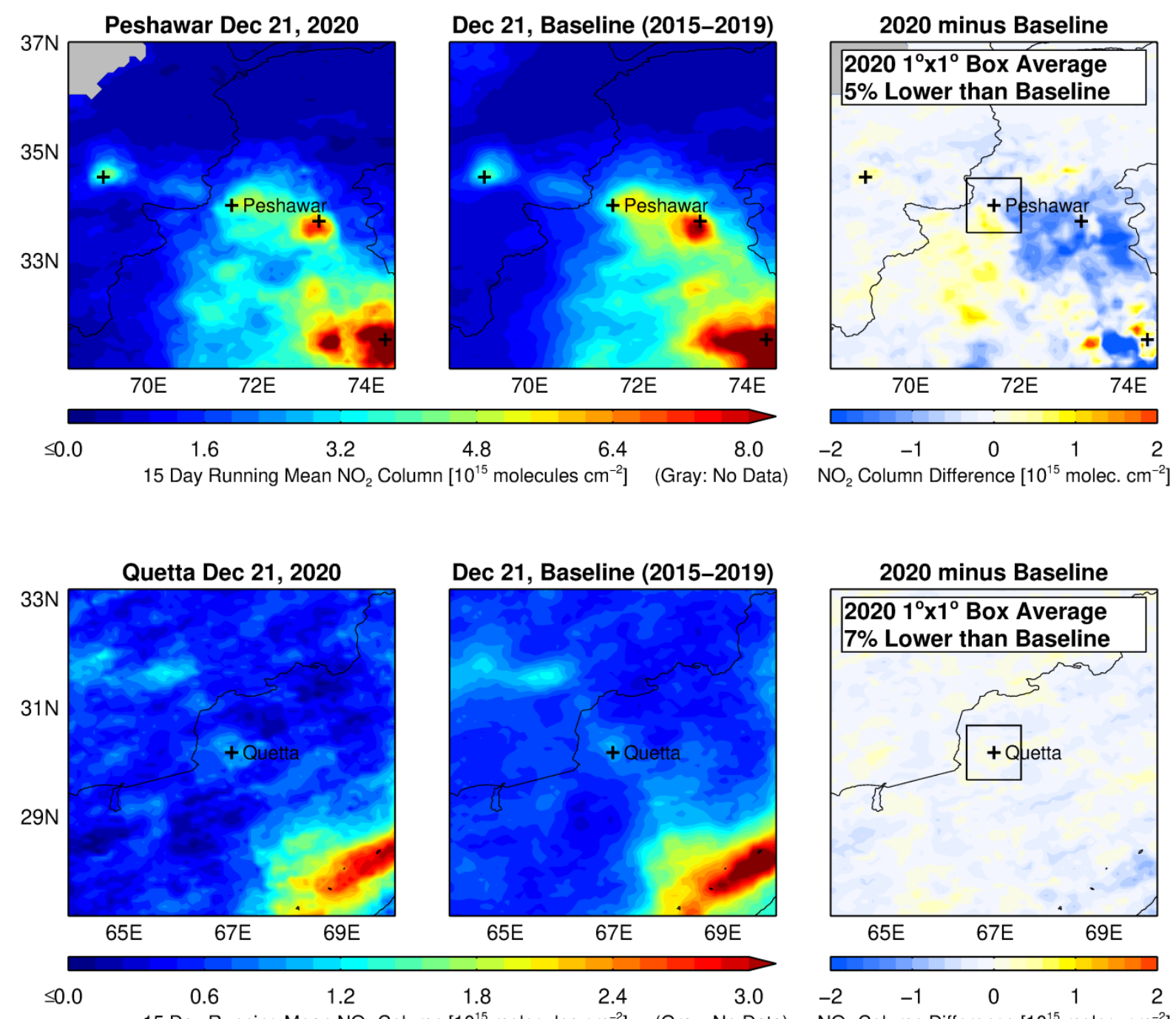

Figure 1: NO2 emissions scenario in mega cities of Pakistan; Data Sources: NASA (2021a)

15 Day Running Mean $\mathrm{NO}_{2}$ Column $\left[10^{15}\right.$ molecules $\left.\mathrm{cm}^{-2}\right]$ (Gray: No Data)

$\begin{array}{lllll}-2 & -1 & 0 & 1 & 2 \\ \mathrm{NO}_{2} & \text { Column Difference } & {\left[10^{15}\right.} & \end{array}$ 


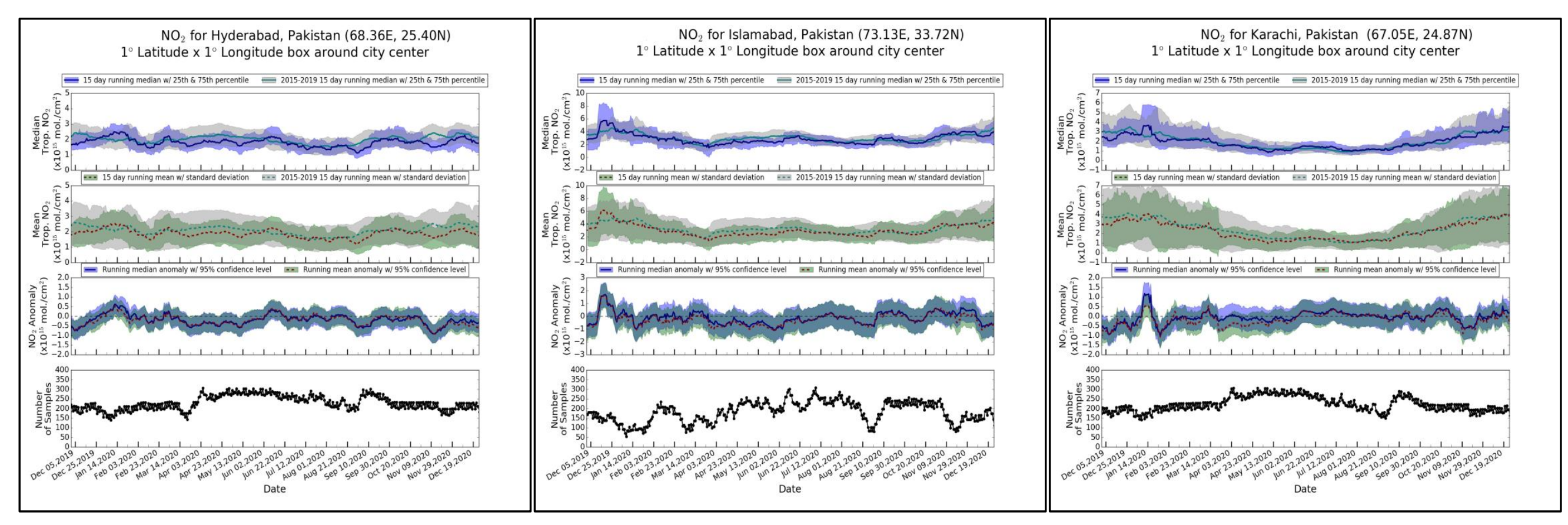




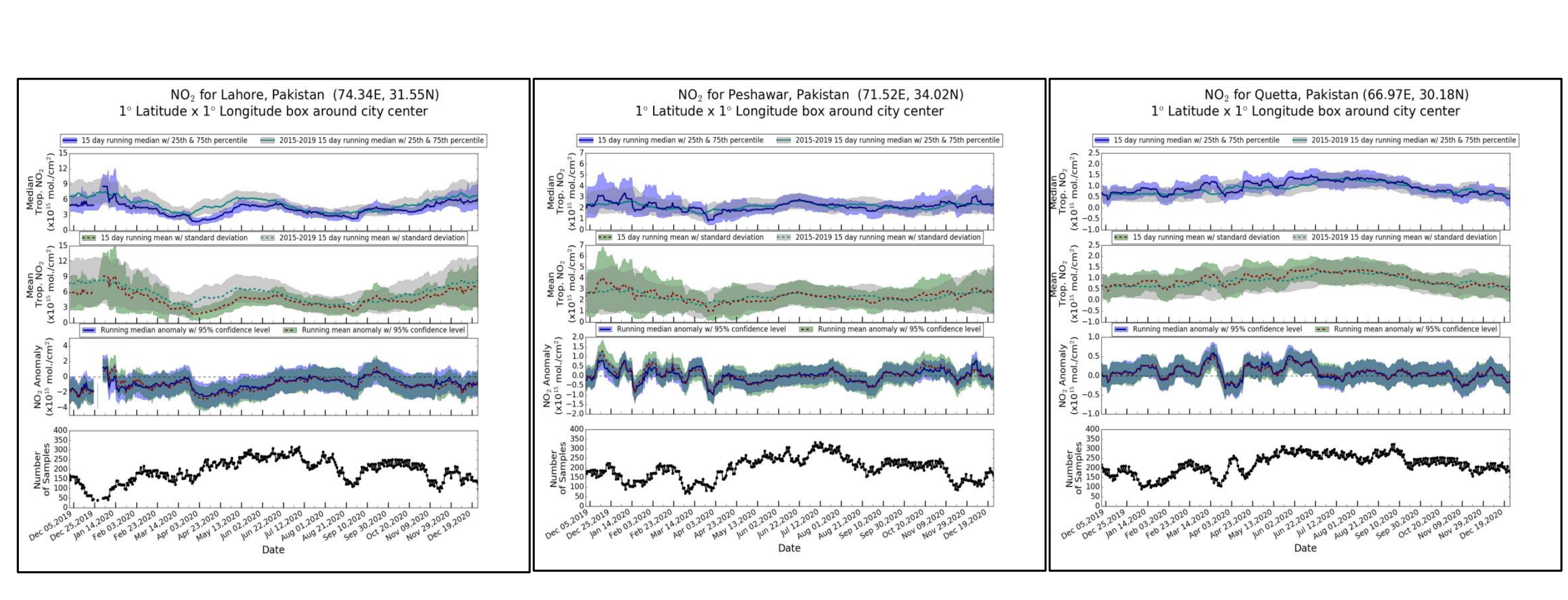

Figure 2: NO2 emissions trend in mega cities of Pakistan; Data Sources: NASA (2021a)

$\sqrt{3}$

(1)

10
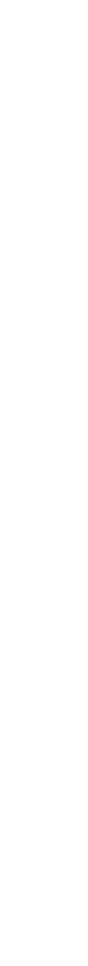

(

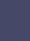

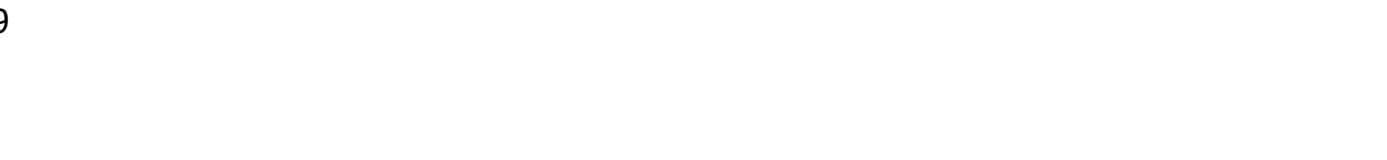



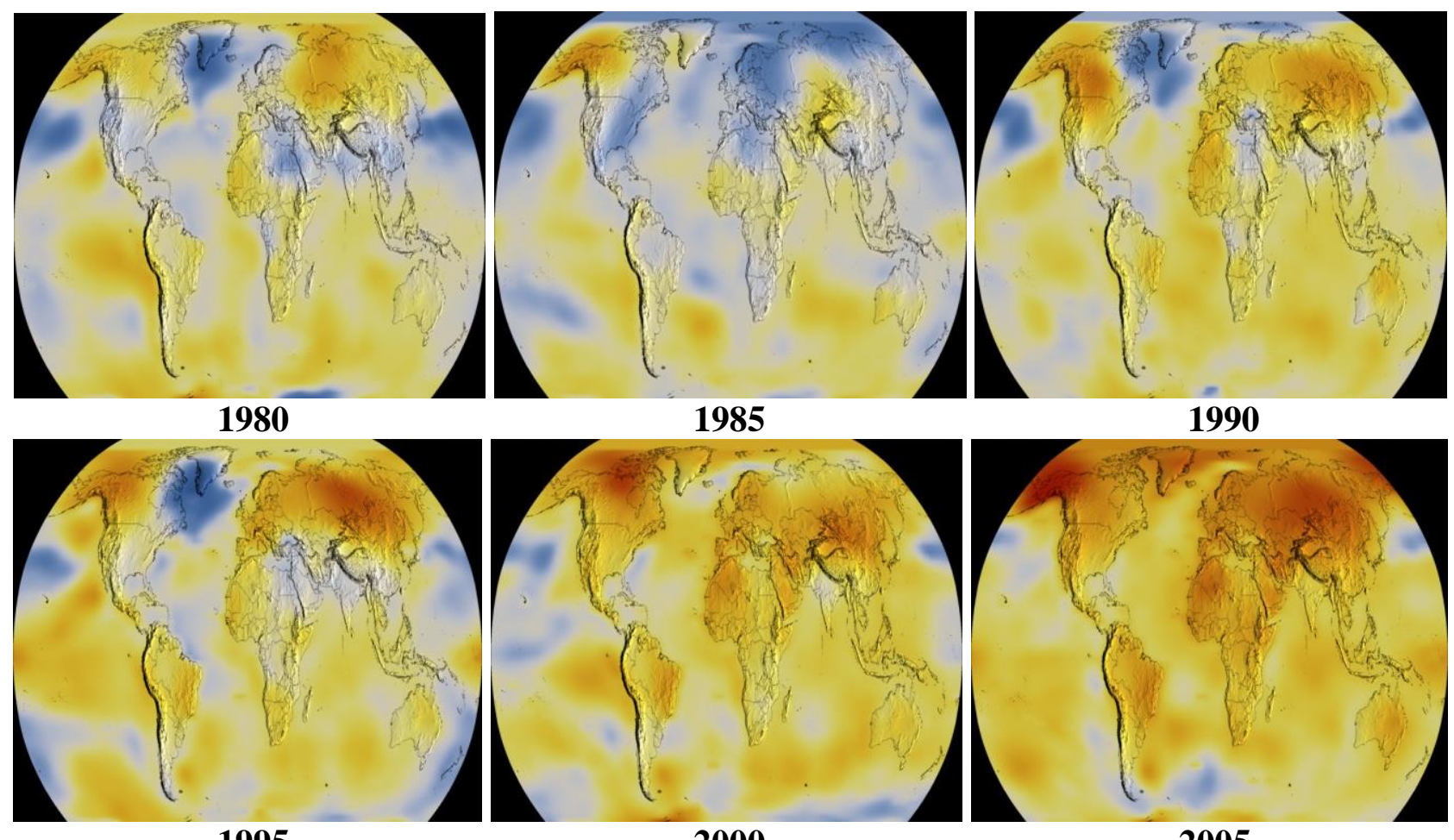

1995

2000

2005

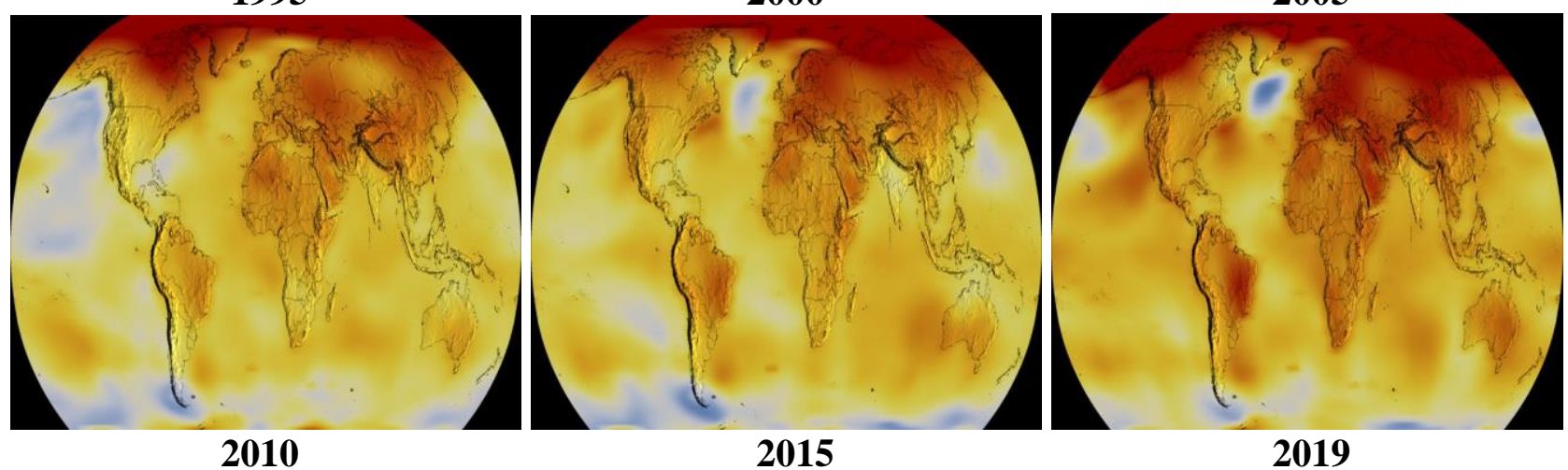

Figure 3: Temperature variation in the World (Fahrenheit) from 1980-2019; Data Sources: NASA (2021b) 

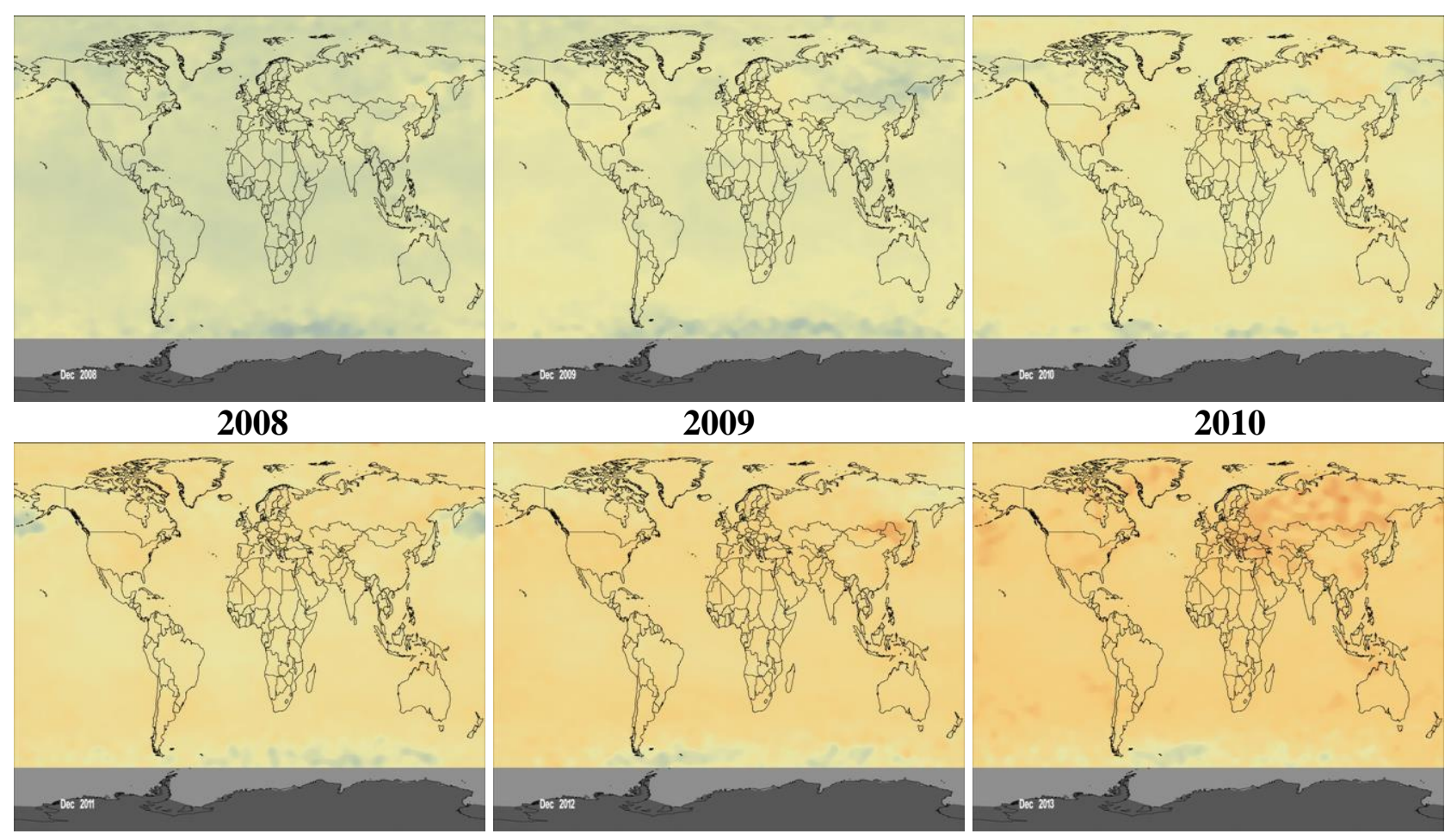

2011

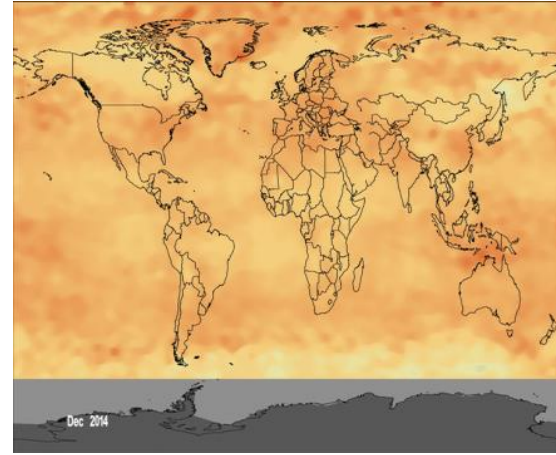

2014
2012

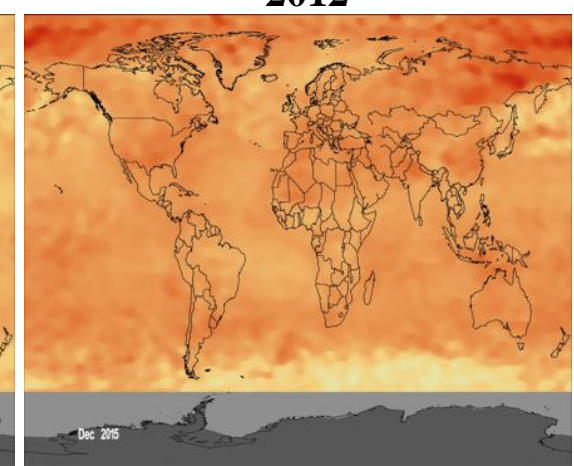

2015
2013

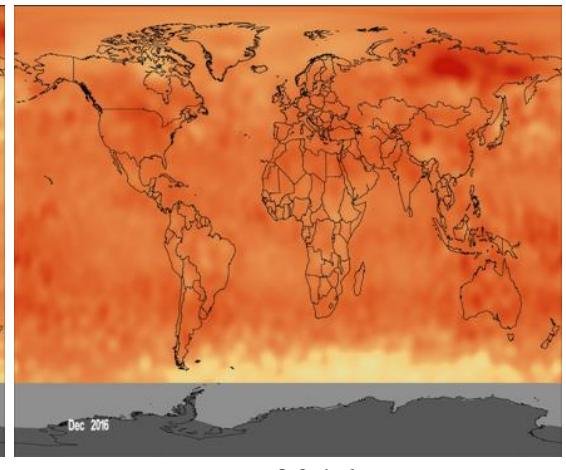

2016

Figure 4: Trend of CO2 emissions globally from 2008-2016; Data sources: NASA (2021c) 
Figure 4 indicates the CO2 pollution scenario in the world from 2008-2016, which shows how carbon dioxide emission has increased with the passage of time. A significant environmental challenge to the global energy system is the possibility of climatic change arising through carbon dioxide emissions from fossil fuels.

\section{Conclusion}

The latest COVID-19 has a positive and negative environmental effect, but this influence would be stronger and more serious in the extended period. The global pandemic (COVID19) is a major problem for public health, culture and the climate, even if economic activities have ceased. However, a mysterious gift is often considered, where air waste reduces and biodiversity is restored. This is strongly connected to natural and economic emissions. The decline in industrial development has had an important effect on the overall trend of energy use and deteriorated the output of emissions. However, reducing environment waste briefly and greenhouse gas emissions in the emergency of COVID-19 is not a feasible option to preserve our biodiversity. This disease has an impact on human health, the international economy and the atmosphere and climate, specifically or partially. It is considered how natural components are ignored and how human influences on the climate change. Furthermore, the global reaction to COVID-19 has allowed us to collaborate in the battle against human threats. Though COVID-19 has a particular impact on the atmosphere, resilience and time-sensitive interventions will improve environmental protection and safeguard the world against the impacts of global warming.

\section{Ethics approval and consent to participate}

Not applicable

\section{Consent for publication}

Not applicable

\section{Availability of data and materials}

Not applicable

\section{Competing Interests}

The authors declare that they have no competing interests. 


\section{Funding}

This research didn’t receive any financial support.

\section{References}

Bahukhandi K, Agarwal S, Singhal S (2020) Impact of lockdown Covid-19 pandemic on himalayan environment. International Journal of Environmental Analytical Chemistry, 1-15. https://doi.org/10.1080/03067319.2020.1857751

Bashir MF, Benghoul M, Numan U, Shakoor A, Komal B, Bashir MA, Bashir M, Tan D (2020) Environmental pollution and COVID-19 outbreak: insights from Germany. Air Quality, Atmosphere \& Health, 13(11), 1385-1394. https://doi.org/10.1007/s11869-02000893-9

Chen F, Chen Z (2021) Cost of economic growth: Air pollution and health expenditure. Science of The Total Environment, 755, 142543. https://doi.org/10.1016/j.scitotenv.2020.142543

Cheung CW, He G, Pan Y (2020) Mitigating the air pollution effect? The remarkable decline in the pollution-mortality relationship in Hong Kong. Journal of Environmental Economics and Management, 102316. https://doi.org/10.1016/j.jeem.2020.102316

Dutheil F, Baker JS, Navel V (2020) COVID-19 as a factor influencing air pollution?. Environmental Pollution (Barking, Essex: 1987), 263, 114466. https://doi.org/10.1016/j.envpol.2020.114466

Eroğlu H (2020) Effects of Covid-19 outbreak on environment and renewable energy sector. Environment, Development and Sustainability, 1-9. https://doi.org/10.1007/s10668-020-00837-4

Hayes K, Blashki G, Wiseman J, Burke S, Reifels L (2018) Climate change and mental health: risks, impacts and priority actions. International Journal of Mental Health Systems, 12(1), 1-12. https://doi.org/10.1186/s13033-018-0210-6

Howard C, Huston P (2019) Climate change and infectious diseases: the solutions: the health effects of climate change: know the risks and become part of the solutions. Canada Communicable Disease Report, 45(5), 114. https://doi.org/10.14745/ccdr.v45i05a01

Hussain A, Arif SM, Aslam M (2017) Emerging renewable and sustainable energy technologies: State of the art. Renewable and Sustainable Energy Reviews, 71, 12-28. https://doi.org/10.1016/j.rser.2016.12.033

Jia Q, Guo Y, Wang G, Barnes SJ (2020) Big data analytics in the fight against major public health incidents (Including COVID-19): a conceptual framework. International journal of environmental research and public health, 17(17), 6161. https://doi.org/10.3390/ijerph17176161

Khare V, Nema S, Baredar P (2016) Solar-wind hybrid renewable energy system: A review. Renewable and Sustainable Energy Reviews, 58, 23-33. https://doi.org/10.1016/j.rser.2015.12.223

Le VV, Huynh TT, Ölçer A, Hoang AT, Le AT, Nayak SK, Pham VV (2020) A remarkable review of the effect of lockdowns during COVID-19 pandemic on global PM 
emissions. Energy Sources, Part A: Recovery, Utilization, and Environmental Effects, 1-16. https://doi.org/10.1080/15567036.2020.1853854

Lokhandwala S, Gautam P (2020) Indirect impact of COVID-19 on environment: A brief study in Indian context. Environmental research, 188, 109807. https://doi.org/10.1016/j.envres.2020.109807

Manigandan S, Atabani AE, Ponnusamy VK, Pugazhendhi A, Gunasekar P, Prakash S (2020a) Effect of hydrogen and multiwall carbon nanotubes blends on combustion performance and emission of diesel engine using Taguchi approach. Fuel, 276, 118120. https://doi.org/10.1016/j.fuel.2020.118120

Manigandan S, Wu MT, Ponnusamy VK, Raghavendra VB, Pugazhendhi A, Brindhadevi K (2020b) A systematic review on recent trends in transmission, diagnosis, prevention and imaging features of COVID-19. Process Biochemistry. https://doi.org/10.1016/j.procbio.2020.08.016

Maroušek J, Kolář L, Strunecký O, Kopecký M, Bartoš P, Maroušková A, Cudlínová E, Konvalina P, Šoch M, Moudrý Jr J, Vaníčková R (2020) Modified biochars present an economic challenge to phosphate management in wastewater treatment plants. Journal of Cleaner Production, 272, 123015. https://doi.org/10.1016/j.jclepro.2020.123015

Muhammad S, Long X, Salman M (2020) COVID-19 pandemic and environmental pollution: a blessing in disguise?. Science of The Total Environment, 138820. https://doi.org/10.1016/j.scitotenv.2020.138820

NASA (2021a). https://earthobservatory.nasa.gov/images.

NASA (2021b). https://climate.nasa.gov/vital-signs/global-temperature.

NASA (2021c). https://climate.nasa.gov/vital-signs/carbon-dioxide.

Nižetić S (2020) Impact of coronavirus (COVID-19) pandemic on air transport mobility, energy, and environment: A case study. International Journal of Energy Research, 44(13), 10953-10961. https://doi.org/10.1002/er.5706

Pani SK, Wang SH, Lin NH, Chantara S, Lee CT, Thepnuan D (2020) Black carbon over an urban atmosphere in northern peninsular Southeast Asia: Characteristics, source apportionment, and associated health risks. Environmental Pollution, 259, 113871. https://doi.org/10.1016/j.envpol.2019.113871

Requia WJ, Mohamed M, Higgins CD, Arain A, Ferguson M (2018) How clean are electric vehicles? Evidence-based review of the effects of electric mobility on air pollutants, greenhouse gas emissions and human health. Atmospheric Environment, 185, 64-77. https://doi.org/10.1016/j.atmosenv.2018.04.040

Rupani PF, Nilashi M, Abumalloh RA, Asadi S, Samad S, Wang S (2020) Coronavirus pandemic (COVID-19) and its natural environmental impacts. International Journal of Environmental Science and Technology, 1-12. https://doi.org/10.1007/s13762-02002910-X

Saravanan M (2020) Exploitation of artificial intelligence for predicting the change in air quality and rain fall accumulation during COVID-19. Energy Sources, Part A: Recovery, Utilization, and Environmental Effects, 1-10. https://doi.org/10.1080/15567036.2020.1834646 
Vochozka M, Horák J, Šuleř P (2019) Equalizing Seasonal Time Series Using Artificial Neural Networks in Predicting the Euro-Yuan Exchange Rate. Journal of Risk and Financial Management, 12(2), 76. https://doi.org/10.3390/jrfm12020076

Wang P, Chen K, Zhu S, Wang P, Zhang H (2020) Severe air pollution events not avoided by reduced anthropogenic activities during COVID-19 outbreak. Resources, Conservation and Recycling, 158, 104814. https://doi.org/10.1016/j.resconrec.2020.104814

WHO (2020). Air Pollution http://www9.who.int/airpollution/en/

Wu X, Nethery RC, Sabath MB, Braun D, Dominici F (2020) Air pollution and COVID-19 mortality in the United States: Strengths and limitations of an ecological regression analysis. Science advances, 6(45), eabd4049. https://doi.org/10.1126/sciadv.abd4049

Wu Y, Jing W, Liu J, Ma Q, Yuan J, Wang Y, Du M, Liu M (2020) Effects of temperature and humidity on the daily new cases and new deaths of COVID-19 in 166 countries. Science of the Total Environment, 139051. https://doi.org/10.1016/j.scitotenv.2020.139051

Zhang Z, Xue T, Jin X (2020) Effects of meteorological conditions and air pollution on COVID-19 transmission: Evidence from 219 Chinese cities. Science of the Total Environment, 741, 140244. https://doi.org/10.1016/j.scitotenv.2020.140244 